\title{
TWO-STEP GRAFTING OF THE FULL THICKNESS SKIN DEFECTS IN PIGS USING THE COMPOSITE OF ATELOCOLLAGEN AND HYALURONIC ACID
}

\author{
P. BRYCHTA ${ }^{1}$, J. ADLER ${ }^{2}$, D. HORKÝ ${ }^{3}$, R. MAGER ${ }^{1}$, J. LORENZOVÁ $^{4}$, \\ M. FRANCŮ ${ }^{1}$, A. GALATÍK ${ }^{5}$ \\ ${ }^{1}$ Burns and Reconstructive Surgery Centre, ${ }^{2}$ Tissue Bank, University Hospital Brno-Bohunice \\ ${ }^{3}$ Department of Histology and Embryology, Medical Faculty, Masaryk University Brno \\ ${ }^{4}$ Department of Surgery, University of Veterinary and Pharmaceutical Sciences Brno \\ ${ }^{5}$ HYPRO Otrokovice
}

Received March 3, 1999

Accepted May 31, 2000

\section{Abstract}

Brychta, P, J. Adler, D. Horký, R., Mager, J. Lorenzová, M. Franců, A. Galatík.: Two-step Grafting of the Full Thickness Skin Defects in Pigs Using the Composite of Atelocollagen and Hyaluronic Acid. Acta Vet. Brno, 2000, 69: 123-129.

The reconstruction of resistant and pliable skin in vivo is not possible without the substitution of its dermal component. To explore the feasibility of two-step grafting of full-thickness skin defects, an animal experiment was carried out. Twelve large white female pigs weighing $30 \mathrm{~kg}$ were used. The full-thickness wounds created were $5 \times 5 \mathrm{~cm}$ in size.

The composite of bovine atelocollagen and hyaluronic acid (HyproDerm) was implanted as the dermal substitute in the first step. The overgrafting of this composite with a thin epidermal autograft followed as the second step ten days later.

Planimetric, histologic and clinical evaluations (using the Vancouver Scar Score) of healed wounds were carried out. Studied wounds were compared with those left for spontaneous healing and those grafted immediately using dermoepidermal graft without any dermal substitute.

1. Planimetric measurements have shown that the average area of the treated defects was $1245.2 \mathrm{~mm}^{2}$, the average area of untreated defects was $386.2 \mathrm{~mm}^{2}$ and the area of immediately grafted defects was $677.8 \mathrm{~mm}^{2}$, one month after the injury. These differences were statistically significant $(p<0.001)$

2. Very good vascularisation and colonisation by fibroblasts with immediate production of collagen fibres, were observed microscopically.

3. The quality of reconstructed skin was superior to the untreated wound according to the modified Vancouver Scar Score (4.91 points) treated wounds $\times 9.25$ points (non-treated wounds) $\times 5.50$ (immediately grafted wounds) after one month.

The dermal substitute HyproDerm reduces the shrinkage of resurfaced wounds and improves the quality of reconstructed skin in pigs. Containing the harmless and approved materials, its convenient for clinical use.

HyproDerm, dermal substitute, epidermal autografts, wound shrinkage, Vancouver Scar Score

The improved survival of severely burned patients - a result of better understanding and management of burn shock and early radical excision of necrotic skin (Pruitt and Mas on 1997) - brought in the past decades the problem of reconstruction of the missing skin. New and/or improved methods of expansion of patient's own skin epithelium were developed as life saving procedures. Cultured autografts are probably the most effective and popular among them (Galli c o et al. 1984; Munster et al. 1990). However, the micrografting (Meek 1996), sandwich grafting (Alexander et al. 1981) and intermingled grafting (Y ang et al. 1980) are also very important.

Nevertheless, for the reconstruction of durable and pliable skin, the renewal of the dermal component seems to be very important (Compton et al. 1989). This fact was recognized about 15 years ago and many attempts have been made to resolve this problem.

Address for correspondence:

Doc. MUDr. Pavel Brychta, CSc.
Burns and Reconstructive Surgery Centre,

Burns and Reconstructive Surgery Cent

Jihlavská 20, 63900 Brno, Czech Republic

Phone: +42054319 ???

Fax: +420543192382

http://www.vfu.cz/acta-vet/actavet.htm 
This paper describes one of the possible ways of dermal replacement: two-step grafting of full thickness skin defects in pigs using the composite of atelocollagen and hyaluronic acid (HyproDerm) as the first step and its subsequent overgrafting with very thin conventional epidermal autograft as the second step.

\section{Materials and Methods}

Twelve Large White female pigs weighing about $30 \mathrm{~kg}( \pm 2 \mathrm{~kg})$ were used. General anaesthesia was provided using Stresnil, i.m. at a dose of $0.1 \mathrm{ml} / \mathrm{kg}$ and Hypnodil i.v. at a dosis of $0.2 \mathrm{ml} / \mathrm{kg}$ during all procedures.

In each animal 6 full thickness skin defects were created paravertebrally. The size of each defect was $5 \times 5 \mathrm{~cm}$ (Plate III, Fig. 1). The dermal subsitute was immediately applied and fixed either by sutures or staples to the wounds $1-4$

The material consisted of the composite of atelocollagen and hyaluronic acid, as previously described (21). Our modification was called HyproDermTM. Its thickness was 3,5 mm (Plate III, Fig. 2). Thin polyurethan membrane was fixed onto the upper surface of the composite. Metallic staples and protective dressing containing gauze were used to fix the composite in the wound and adhesive tapes were applied at the end of the procedure (Plate IV, Fig. 3).

Two wounds were used as a control: wound No. 5 was left untreated (only covered) for healing per secundam. Wound No. 6 was closed immediately after the defect was created with a thin dermoepidermal graft.

The re-bandage of all wounds was performed on day 3 after the operation (Plate IV, Fig. 4).

Subsequently, 10 days after creation of the defects and dermal substitute application, the polyurethan membrane covering was removed and replaced by the same thin dermoepidermal autografts as wound No. 6 ten days previously. The wound beds showed good vascularisation at this time (Plate V, Fig. 5). Grafts were freshly harvested from the posterior legs. The dermoepidermal grafts were stapled and covered by the elastic bandage (Plate V, Fig. 6).

The samples for the histologic evaluation were taken before the appplication of the epidermal grafts (day 10), 7 days after over-grafting (day 17) and then 21 days after overgrafting, i.e. 31 days after creation of the defects.

At the same time (one month after the wounds were created) the size and shape of them were measured to assess the degree of wound contraction and the Vancouver Scar Score was used for quality assessment of healed defects.

Plate VI, Fig. 7 shows the appearance of a two-step grafted wound one week after overgrafting and Plate VI, Fig. 8 shows the wounds 3 weeks after overgrafting.

The evaluation of results obtained was performed:

a) planimetrically, using our original computer programme

The wounds were covered with sterile transparent membrane and their edges were painted with a surgical pen. Subsequently, the size and shape of wounds were transferred into the computer memory and the area was calculated in the specially developed computer programme.

The aim of this measurement was to follow up the degree of wound contraction in each of the wounds. The question was if the dermal substitute would be able to reduce it effectively.

b) histologically, using light microscopy (HE and AZAN staining)

The aim of this assessment was to follow up the structure of reconstructed skin, process of vascularisation and collagen ingrowth, and in the later phase the formation of new epidermis.

c) clinically, using the Vancouver Scar Score

The Vancouver Scar Score is often used for the description of the scar quality (Sullivan et al. 1990). We used it for the evaluation of all three types of healed wounds.

The scar assessments have been devised based on physical parameters of pigmentation, vascularity, pliability and scar height. All parameters were assessed independently and with increasing score being assigned to the greater pathologic condition.

Pigmentation:

$0=$ Normal: colour that closely resembles the colour over the rest of a person's body

$1=$ Hypopigmentation

$2=$ Hyperpigmentation

Vascularity:

$0=$ normal: colour that closely resembles the colour over the rest of the body

$1=$ pink

$2=$ red

$3=$ purple 
Pliability:

$0=$ normal

1 = supple: flexible with minimal resistance

2 = yielding: giving way to pressure

3 = firm: inflexible, not easily moved, resistant to manual pressure

$4=$ bending: rope-like tissue that blanches with extension of scar

$5=$ contracture: permanent shortening of scar producing deformity of distortion

Height:

$0=$ normal

$1=<2 \mathrm{~mm}$

$2=3-5 \mathrm{~mm}$

$3=>5 \mathrm{~mm}$

Burn Scar assessment form

\begin{tabular}{|c|c|c|c|c|}
\hline Pigmentation & Vascularity & Pliability & Scar height & Total \\
\hline & & & & \\
\hline
\end{tabular}

The results were evaluated using analysis of variance.

\section{Results}

The results of planimetric measurements yielded the following values (Table 1):

Table 1

\begin{tabular}{|c|c|c|c|}
\hline Pig No. & $\begin{array}{c}\text { Wounds } 1-4 \\
\left(\mathrm{~mm}^{2}\right)\end{array}$ & $\begin{array}{c}\text { Wound 5 } \\
\left(\mathrm{mm}^{2}\right)\end{array}$ & $\begin{array}{c}\text { Wound 6 } \\
\left(\mathrm{mm}^{2}\right)\end{array}$ \\
\hline 1 & 1013.6 & 906.5 & 463.1 \\
\hline 2 & 1164.2 & 874.3 & 455.1 \\
\hline 3 & 1203.1 & 594.7 & 459.7 \\
\hline 4 & 1099.9 & 583.6 & 376.5 \\
\hline 5 & 1205.7 & 870.4 & 495.6 \\
\hline 6 & 1345.1 & 781.3 & 435.5 \\
\hline 7 & 1322.9 & 663.6 & 361.8 \\
\hline 8 & 1296.2 & 899.3 & 396.1 \\
\hline 9 & 1606.9 & 464.1 & 390.0 \\
\hline 10 & 1233.6 & 583.4 & 355.1 \\
\hline 11 & 1204.3 & 434.4 & 190.0 \\
\hline 12 & 1246.3 & 478.1 & 256.5 \\
\hline average & 1245.2 & 677.8 & 386.2 \\
\hline value & & & \\
\hline
\end{tabular}

Thirty one days after defect creation the average size of wounds 1 - 4 was $1245 \mathrm{~mm}^{2}$ (SD $146 \mathrm{~mm}^{2}$ ). The average size of wound 5 (healing per secundam) was $678 \mathrm{~mm}^{2}$ (SD $180 \mathrm{~mm}^{2}$ ) and the average size of wound 6 was $386 \mathrm{~mm}^{2}$ (SD $89 \mathrm{~mm}^{2}$ ).

The difference between wounds $1-4$ and wounds 5 is highly statistically significant $(p<0.001)$. The mean difference between wounds $1-4$ and 5 was $567 \mathrm{~mm}^{2}(95 \% \mathrm{CI}$ 396, 739.

The difference between wounds $1-4$ and wounds 6 is also highly statistically significant $(p<0.001)$. The mean difference between wounds $1-4$ and 6 was $859 \mathrm{~mm}^{2}(95 \%$ CI $745,973$.

Thirty one days after wounding, the contraction was most evident in the non-treated wounds (No. 5), followed by the immediately grafted wounds in No. 6. The least contraction was observed in wounds No. 1 - 4 i.e. those with the dermal substitute. 
Table 2

The Vancouver Scar Score

\begin{tabular}{|c|c|c|c|}
\hline Pig No. & Wounds $1-4$ & Wound 5 & Wound 6 \\
\hline 1 & 4.75 & 9 & 6 \\
\hline 2 & 4.5 & 9 & 8 \\
\hline 3 & 5.75 & 8 & 8 \\
\hline 4 & 4.5 & 8 & 4 \\
\hline 5 & 3.75 & 9 & 5 \\
\hline 6 & 6.25 & 10 & 4 \\
\hline 7 & 5.5 & 10 & 4 \\
\hline 8 & 5.75 & 9 & 7 \\
\hline 9 & 5.75 & 10 & 7 \\
\hline 10 & 5.5 & 10 & 3 \\
\hline 11 & 4.75 & 9 & 5.5 \\
\hline 12 & 2.25 & 9.25 & 5 \\
\hline average value & 4.91 & & \\
\hline
\end{tabular}

II. The histologic picture of the wounds was as follows (Plates VII and VIII, Figs 9 - 12):

The main features of the histologic follow up were the quick and intensive ingrowth of cappilaries and collagen fibres into the substitute in the first days. Signs of inflammation were only moderately pronounced. The microscopic picture corresponded with the clinical finding of an almost ideal wound bed for grafting after 10 days of dermal substitute implantation.

In spite of this, the "take" of the grafts was relatively complicated in the histologic pictures. Necrotic areas appeared in the grafts and could be observed in the first days. The remaining living cells (fibroblasts and keratinocytes) were nevertheless able to form the new epidermis of quite a good quality (see Figs 9 - 12).

\section{The Vancouver Scar Score}

The mean difference between wounds 1 - 4 and wounds 5 was 4.3 (95\% CI 3.7, 5.0). This difference was highly significant $(p<0.001)$.

The mean difference between wounds 1 - 4 and wounds 6 was $0.6(95 \%$ CI $0.5,1.6)$ This difference was not statistically significant $(p<0.253)$

There was a conspicuous difference between wounds 1 - 4 and the wound 5 (untreated wound) in the degree of scarring. Less difference between the same wounds and wound 6 (immediately grafted) could be observed.

\section{Other observations made:}

1. No difference could be found between the sutured (4.0 or 5.0 monofilament suture) and stapled grafts. Staples are quicker and easier to insert than sutures. No clinically significant irritation could be observed in either of the materials and both materials remained patent and safely fixed the dermal implant during the whole course of the experiment.

2. The 10-day interval between the implantation of dermal substitute and its overgrafting seems to be sufficient. At this time the tissue was freshly red and sometimes even slightly exceeding the level of surrounding skin (Fig. 5).

3. The first step of the procedure - dermal substitute implantation - is technically much easier than the second step - a successful "take" of the dermoepidermal graft on top of it. 


\section{Discussion}

The replacement of dermis at present is performed using either the allogeneic acellular dermis (Pruniears et al. 1979; Heck et al. 1984; Cuono et al. 1986; Cuono et al. 1987) or using any form of collagen with (Bell et al. 1979; Boyce and Hansbrough 1988) or without autologous fibroblasts (Yannas and Burke 1980; Burke et al. 1981). Other synthetic biodegradable materials have also been used (Hansbrough et al. 1992; Van Dorp et al. 1998).

In Slovakia, group of research workers explores a very similar material which differs from the presented one mainly in the cross-linking procedure (Koller et al. 1997; Vizárová et al. 1994; Vizárová et al. 1995).

Although the results obtained are convincing, the following topics should be taken into consideration:

1. Although pigs are probably the most suitable animals for the experimental reconstruction of skin, they are relatively complicated to treat and preventing them from damaging their wounds is problematic. The proper wound coverage must be reached and in spite of this it is hard to distinguish if the complicated dermoepidermal graft "take" is caused by its poor nourishment or by friction forces.

2. Assessing the wound contraction makes the use of any chambers, separating the wound from the surrounding skin, impossible. The growth of keratinocytes from the edges therefore takes part in the re-epithelisation of the wounds.

3. Due to the progressive adiposis and growth of the white domestic pigs it becomes impossible to ensure a reproducible long-term follow up.

4. The production of collagen and its reformation to fibrils and fibres is very impressive in the substitute. It is very probable that the results can be extrapolated for human wound healing. Also the vascularisation of the substitute is very quick and intensive.

5. As all the components of the dermal substitute used are known to be harmless for the wound, and the technology of their production corresponds to good laboratory practice, the obtained results therefore justify the clinical use of developed material.

In conclusion, the composite dermal substitute HyproDerm consisting of the mixture of atelocollagen and hyaluronic acid brought satisfactory results in our pig study. In comparison with the wound healing per secundam and even with the wound grafted immediately after wound creation, the wound shrinkage was much less pronounced 31 days after the operation. These results were statistically significant $(p<0.001)$. Also the quality of reconstructed skin assessed by the Vancouver Scar Score was significantly better than that of the non-treated wound $(p<0.001)$. Although this quality was even better than that of the wound grafted immediately, the difference is not statistically significant $(p=0.253)$.

\section{Dvojdobá transplantace kožních defektů plné tloušt'ky u prasat s využitím atelokolagenu a kyseliny hyaluronové}

Rekonstrukce pevné a poddajné kůže in vivo není možná bez náhrady její dermální komponenty.

K výzkumu možnosti dvoudobé transplantace kožních defektů plné tlouštky bylo využito zvířecího experimentu. Bylo použito dvanáct prasnic plemene velké bílé vážících $30 \mathrm{~kg}$. Vytvořené defekty $\mathrm{v}$ plné tlouště měly rozměr $5 \times 5 \mathrm{~cm}$.

V první době byla do defektů implantována jako dermální náhrada složenina bovinního atelokolagenu a kyseliny hyaluronové (HyproDerm). Po deseti dnech byl ve druhé době tento kompozit zatransplantován tenkým epidermálním štěpem.

U zhojených ran byla provedena planimetrická, histologická a klinická hodnocení pomocí 
„Vancouverského skóre“ pro posuzování jizev (Vancouver Scar Score). Sledované rány byly porovnávány s defekty ponechanými ke spontánnímu hojení a defekty ihned zatransplantovanými dermoepidermálním štěpem bez dermální náhrady.

1. Planimetrická měření ukázala, že měsíc po vytvoření ran byla průměrná plocha u zkoumaných defektů $1245,2 \mathrm{~mm}^{2}$, u neléčených defektů $386,2 \mathrm{~mm}^{2}$ a u defektů ihned transplantovaných $677,8 \mathrm{~mm}^{2}$. Tyto výsledky byly statisticky signifikantní $(p<0,001)$.

2. Mikroskopicky byla pozorována velice dobrá vaskularizace a kolonizace fibroblasty s okamžitou produkcí kolagenních vláken.

3. Kvalita rekonstruované kůže byla po měsíci lepší než u neléčených ran (podle modifikovaného „Vancouverského skóre“ ) 4,91 bodů (sledované defekty) $\times 9,25$ bodů (kontrolní defekty bez léčby) $\times 5,50$ bodů (okamžitě transplantované defekty).

U prasat redukuje dermální náhrada HyproDerm kontrakci zhojených defektů a zlepšuje kvalitu obnovené kůže. Vzhledem k tomu, že obsahuje schválené neškodné materiály, je vhodná i pro klinické použití.

\section{Acknowledgement}

This research project was supported by IGA MZ CR No. 3725-3.

\section{References}

ALEXANDER, J. W., MACMILLAN, B. G., LAW, E., KITTUR, D. S. 1981: Treatment of severe burns with widely meshed skin autograft and meshed skin allograft overlay. J. Trauma 21: 433-438

BELL, E., IVARSSON, B., MERRIL, C. 1979: Production of a tissue-like structure and contraction of collagen lattices by human fibroblasts of different proliferative potential in vitro. Proc Natl Acad Sci USA, 76:1274-1278

BOYCE, S. T., HANSBROUGH, J. F. 1988: Biologic attachment, growth, and differantiation of cultured human epidermal keratinocytes on a graftable collagen and chondroitin-6 sulfate substrate. Surgery 103: 421-431

BRYCHTA, P., ADLER, J. 1999: The preparation and use of the dermal substitute HyproDerm. Patent application

BURKE, S. F., YANNAS, I. V., QUINLEY, W. C., et al. 1981: Successful use of a physiologically acceptable artificial skin in the treatment of extensive burn injury. Ann. Surg. 194: 413-428

COMPTON, C. C., GILL, J. M., BRADFORD, D. A., REGAUER, S., GALLICO, G. G., O'CONNOR, N. E. 1989: Skin regenerated from cultured epithelial autografts on full-thickness burn wounds from 6 days to 5 years after grafting. Lab. Invest. 60: 600-612

CUONO, C. B., LANGDON, R., MCGUIRE, J. 1986: Use of cultured autografts and dermal allografts as skin replacement after burn injury. Lancet 1: 1124

CUONO, C. B., LANGDON, R., BIRCHALL, N., BARTTELBORT, S., McGUIRE, J. 1987: Composite autologous -allogeneic skin replacement: development and clinical application. Plast. Reconstr. Surg. 80: 626-635

GALliCO, G. G., O'CONNOR, N. E., GREEN, H. 1984: Permanent coverage of large burn wounds with autologous cultured human epithelium. N Engl. J. Med. 311: 448-451

HANSBROUGH, J. F., COOPER, M. I., DORE, C., SPIELVOGEL, R. L. 1992: Initial clinical studies of a cultured dermal tissue in the treatment of full-thickness burns. Proc 24th Am Burn Assoc Mtg. p. 149

HECK, E. L., BERGSTRESSER, P. R., BAXTER, C. R. 1984: Composite skin graft: frozen dermal allografts support the engraftment and expansion of autologous epidermis. Proc 16th Am Burn Assoc Mtg. p. 96

KOLLER, J., PANÁKOVÁ, E., DRAGUNOVÁ, J. 1997: Preliminary experimental studies of a new biosynthetic dermal substitute Colladerm H. 6th International Conference on Tissue Banking, Edinburgh, Scotland, 28-31 October

MEEK, C. P. 1996: Successful microdermagrafting using the meek-wall microdermatome. Am. J. Surgery 172: 557-558

MUNSTER, A. M., WEINER, S. H., SPENCE, R. J. 1990: Cultured epidermis for the coverage of massive burn wounds: a single centre experience. Ann. Surg. 211: 676-680

PRUIT, B. A. Jr., MASON, D. 1997: Epidemiological, demographic and outcome characteristics of burn injury. In: Total burn care by D. N. Herndon (Ed.). W. B. Saunders Company Ltd, London, pp. 5-15

PRUNIEARS, M., REGNIER, M., SCHLOTTER, M. 1979: A new method to culture human epidermal cells on allogeneic or xenogeneic dermis: preparation of recombined grafts. Ann. Chir. Plast. 24: 357-362

SULLIVAN, T., SMITH, J., KEEMODE, J., MC IVER, E., COURTEMANCHE, D. J. 1990: Rating the burn scar. J. Burn Care and Rehab., May/June, 11: 256-260

VAN DORP, A. G. M., VERHOEVEN, M. C. H., KOERTEN, H. K., TINEKE H., VAN DER NAT- VAN DER MEIJ, T. H., VAN BLITTERSWIJK, C. A., PONEC, M. 1998: Dermal regeneration in full-thickness wounds in Yucatan miniature pigs using a biodegradable copolymer. Wound Repair and Regeneration 6 : 556-568 
VIZÁROVÁ, K., BAKOŠ, D., REHÁKOVÁ, M., MACHO, V. 1994: Modification of layered atelocollagen by ultraviolet irradiation and chemical cross-linking: structure stability and mechanical properties. Biomaterials 15:1082-1086

VIZÁROVÁ, K., BAKOŠ, D., REHÁKOVÁ, M., PETRÍKOVÁ, M., PANÁKOVÁ, E., KOLLER, J. 1995:

Modification of layered atelocollagen: enzymatic degradation and cytotoxicity evaluation. Biomaterials 16:1217-1221

YANNAS, I. V., BURKE, J. F. 1980: Design of an artificial skin. I. Basic design principles. J. Biomed. Mat. Res. 14: $65-81$

YANG, C. C., SHIH, T. S., CHU, T. A. 1980: The intermingled transplantation of auto- and homografts in severe burns. Burns 6: 141 
Plate III

Brychta P. et al.: Two step Grafting... pp. 123-129

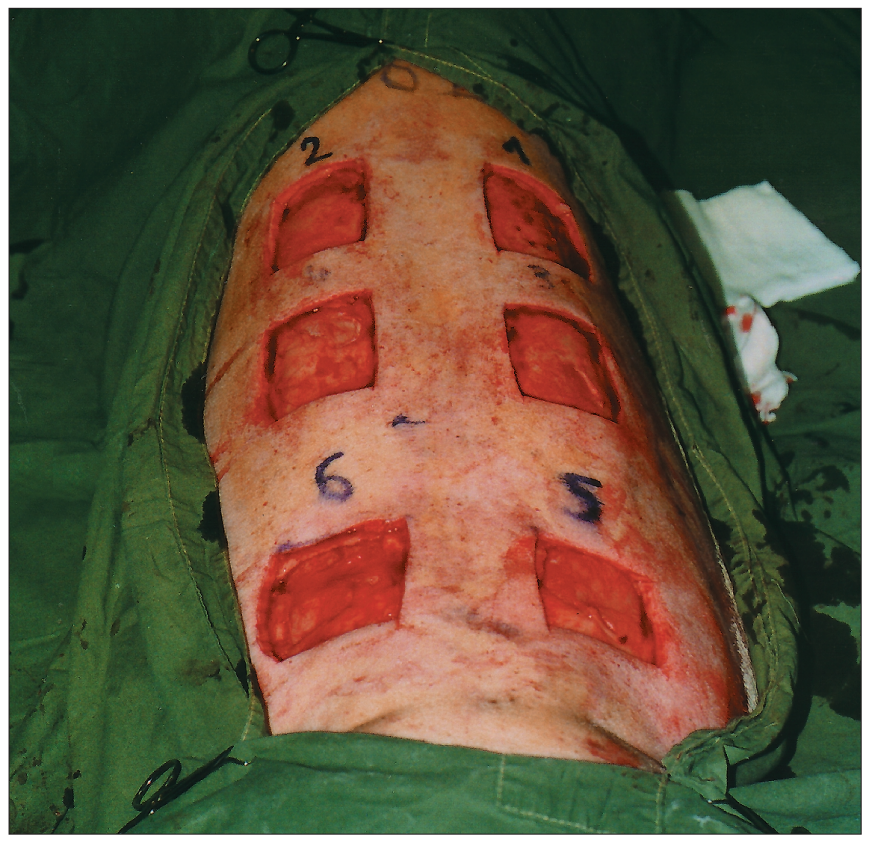

Fig. 1. Large white female pig weighing $30 \mathrm{~kg}$ on the operating table. Six full-thickness skin defects $(5 \times 5 \mathrm{~cm})$ just excised down to the muscle fascia paravertebrally.

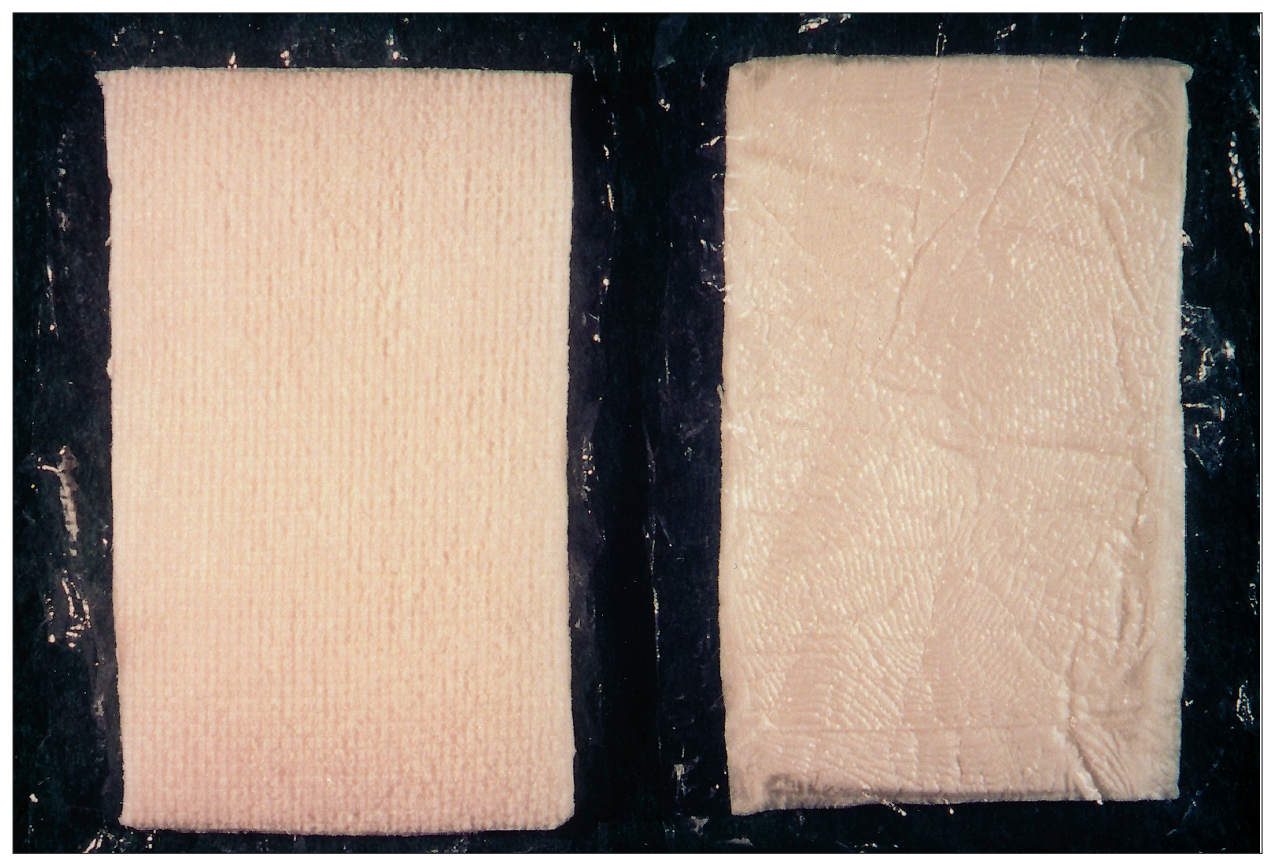

Fig. 2. The composite dermal substitute HyproDermTM consisting of bovine atelocollagen and $6 \%$ hyaluronic acid. Polyurethan membrane fixed on the surface. Size $10 \times 6 \mathrm{~cm}$ 
Plate IV

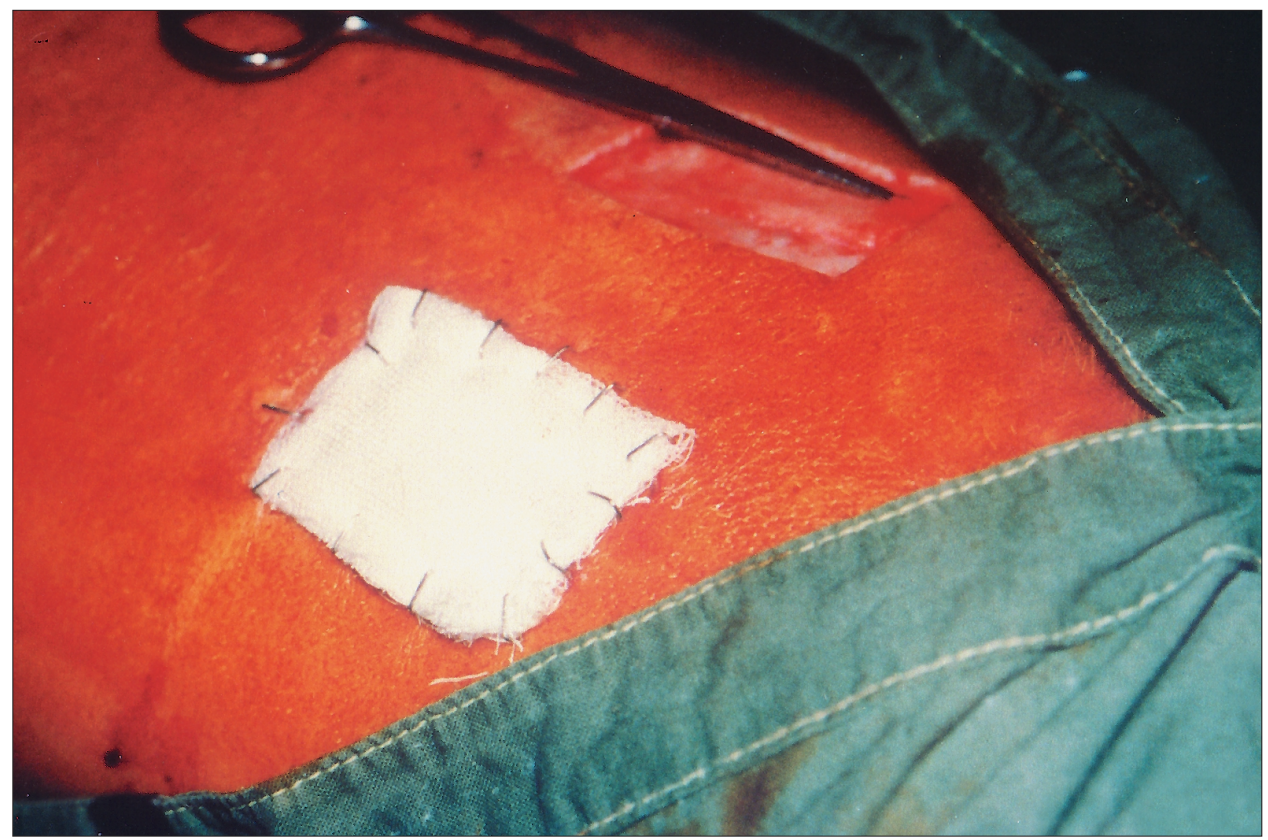

Fig. 3. The composite dermal substitute HyproDermTM fixed with metallic staples onto the experimental wound. Dry gauze dressing on top of the substitute. Right wound still uncovered.

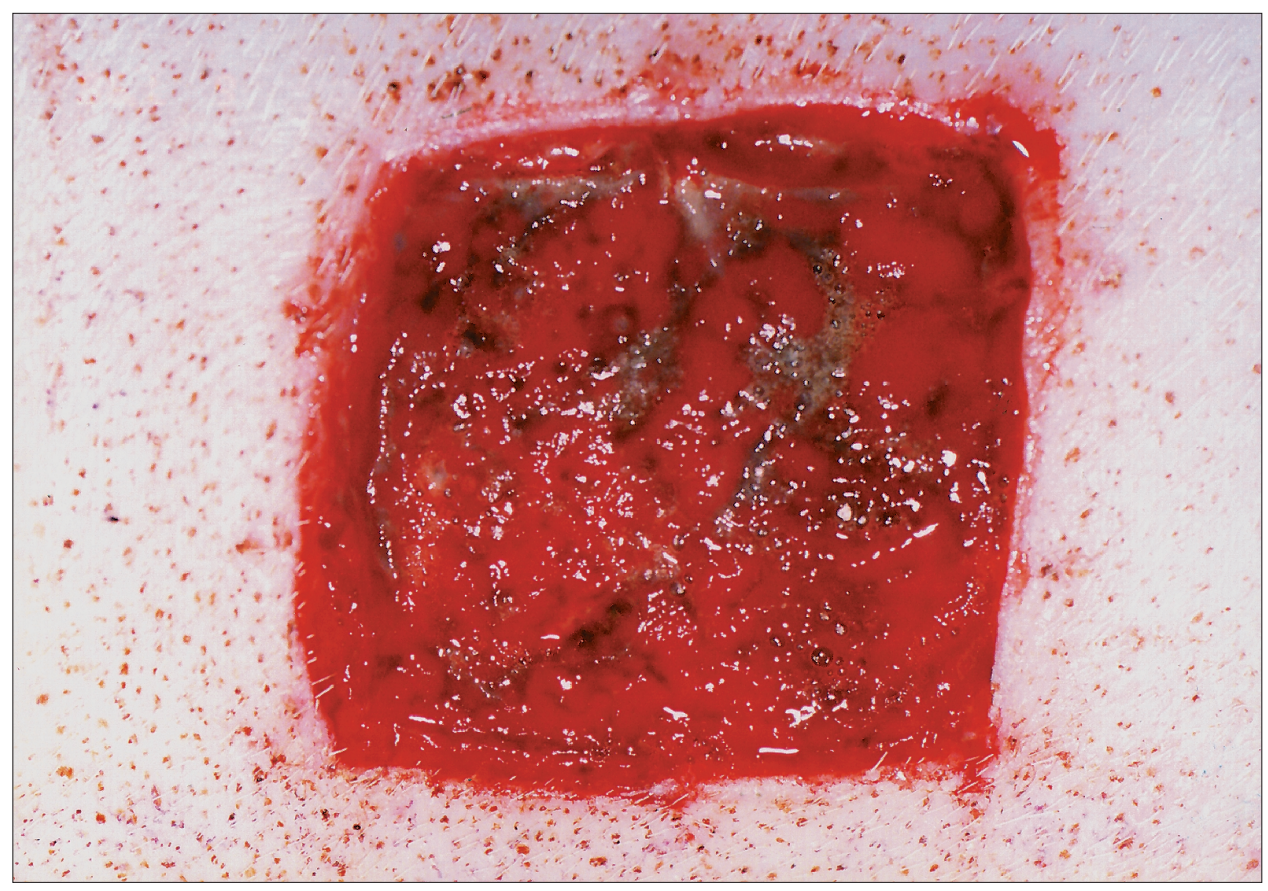

Fig. 4. Situation 3 days later. Substitute soaked with bloody wound secretion. Initial vascularisation can be seen. 
Plate V

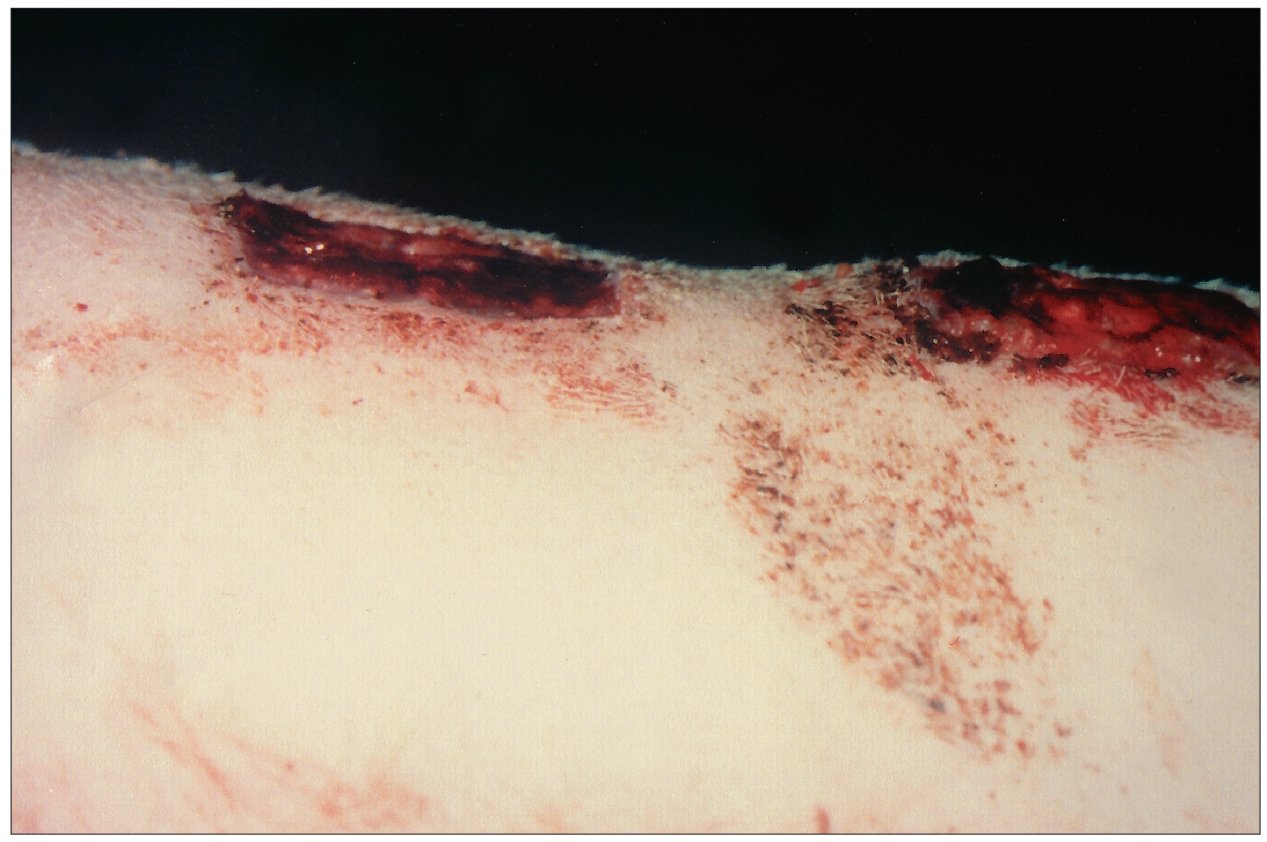

Fig. 5. Ten days after HyproDermTM implantation. The collagen fibres and vessels ingrowth cause the elevated wound bed to exceed the surrounding skin in the right wound. On the left, the control wound 5 (healing per secundam) below the level of surrounding skin.

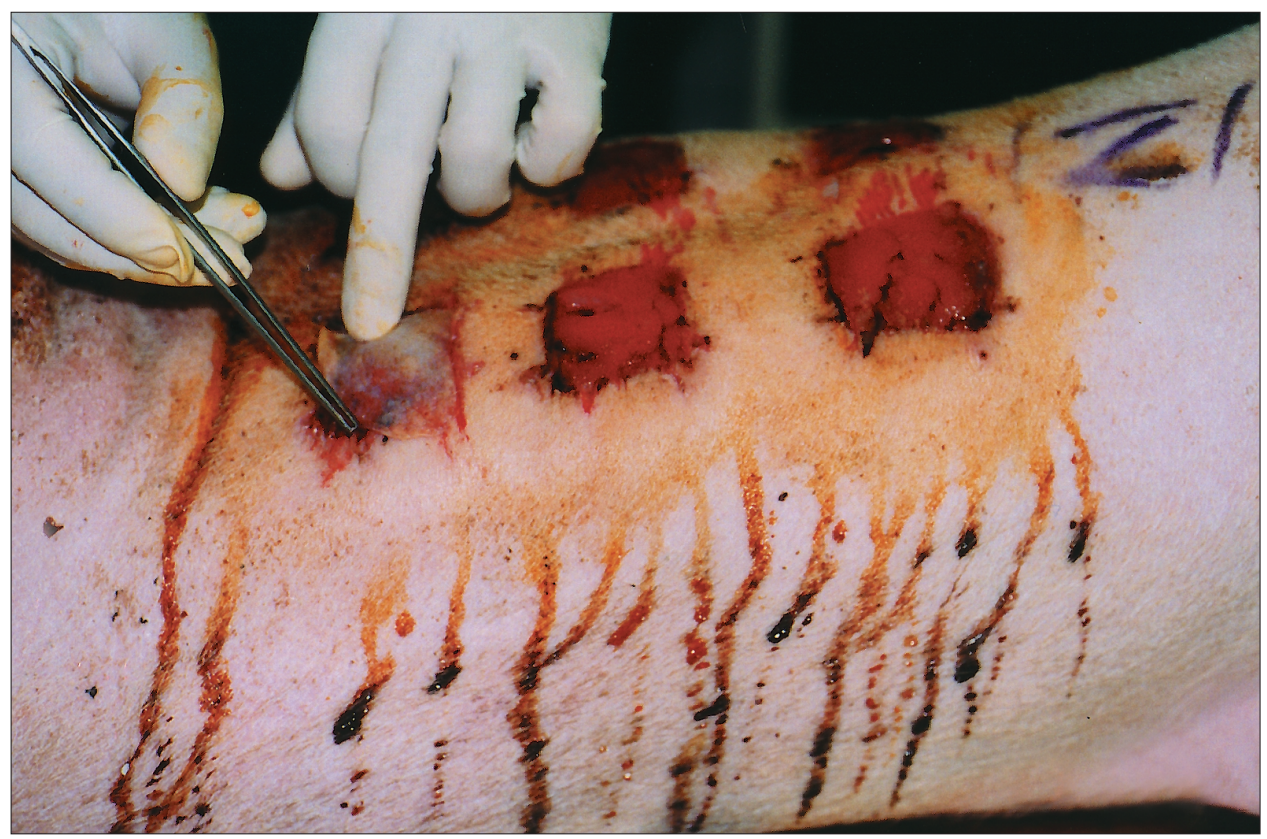

Fig. 6. Overgrafting procedure. Thin dermoepidermal graft adjusted onto the HyproDermTM engrafted dermal substitutes in wounds $1-4$. 
Plate VI

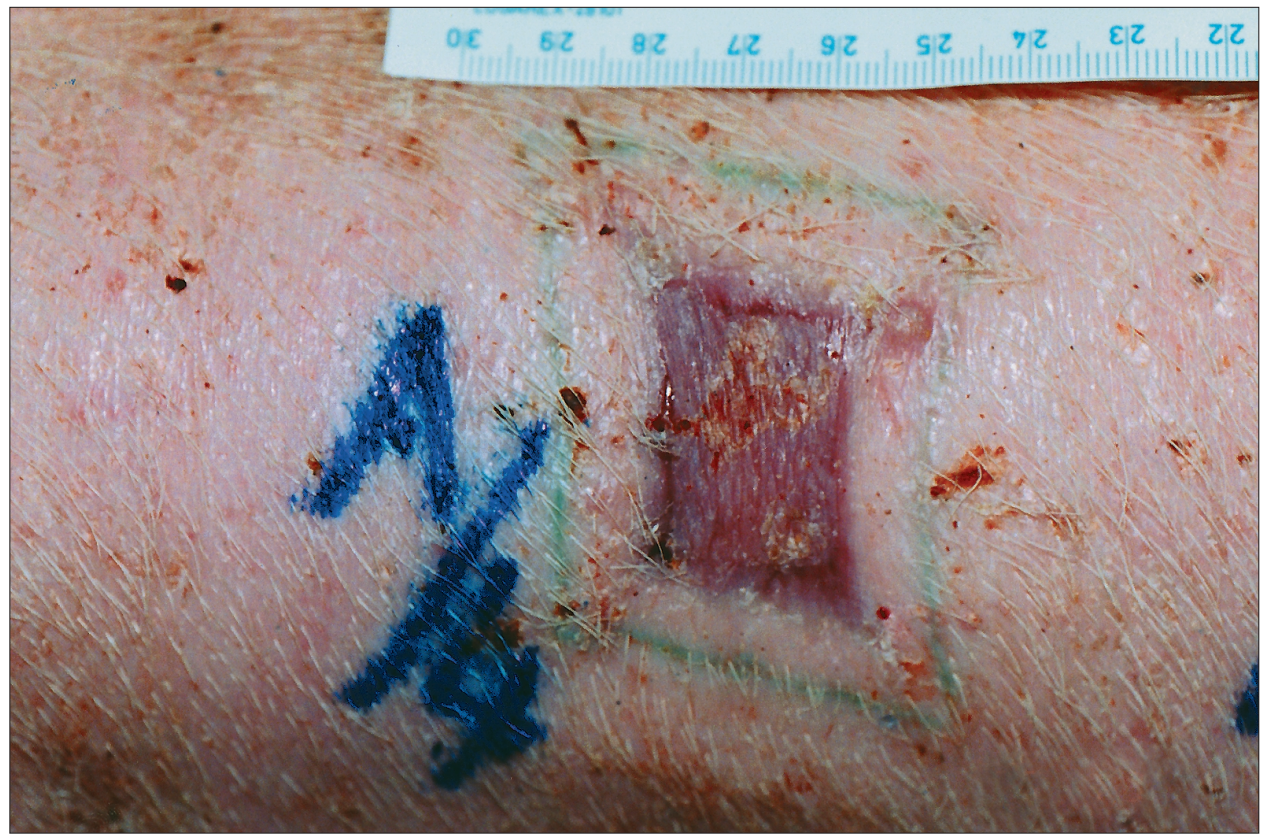

Fig. 7. Completely adhering dermoepidermal graft one week after grafting. Some necrotic material on its surface The red colour caused by the necrosis and loss of the superficial layers of epidermis due to the transitory ischaemia after grafting.

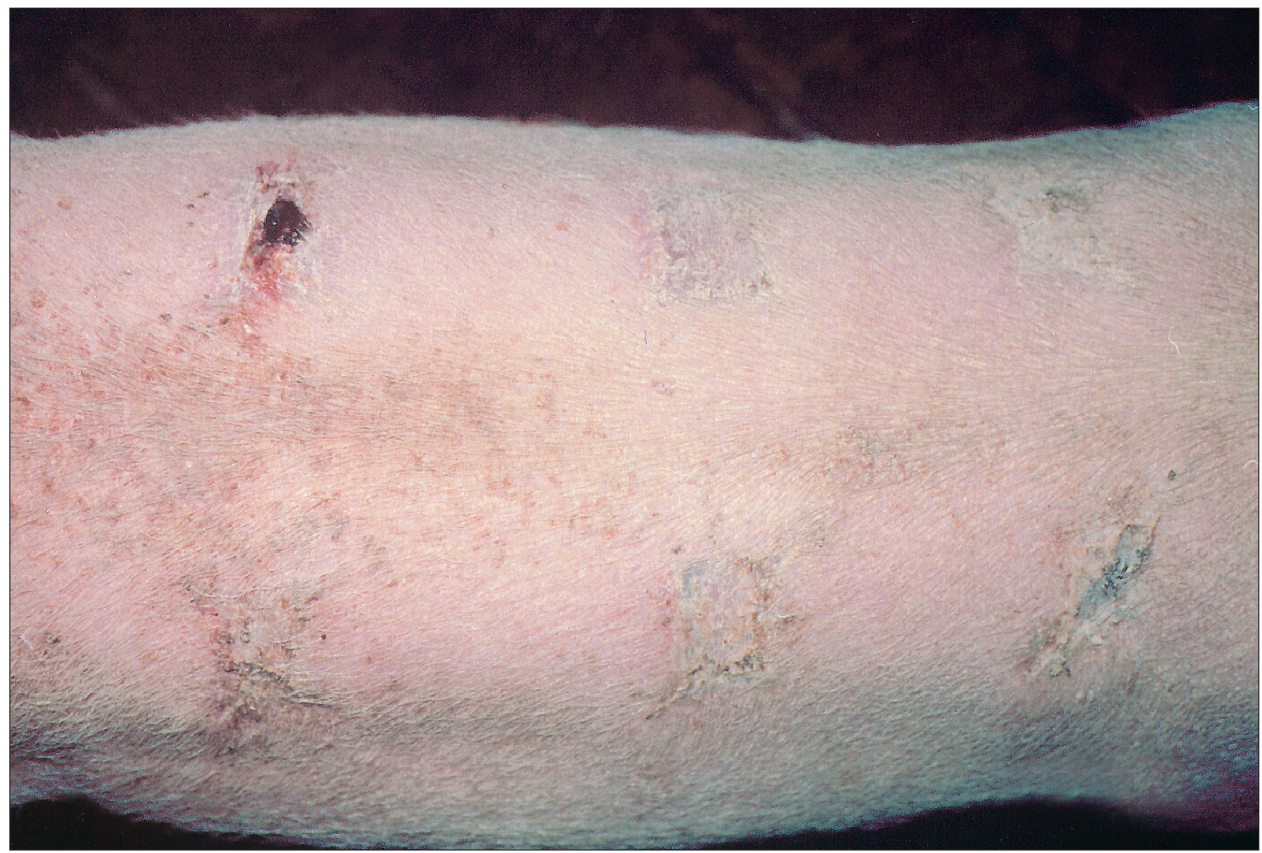

Fig. 8 . The animal one month after experimental injury and 21 days after overgrafting. Note the difference between wounds 1- 4 and wound 5 (upper right), which is not covered by crust. 


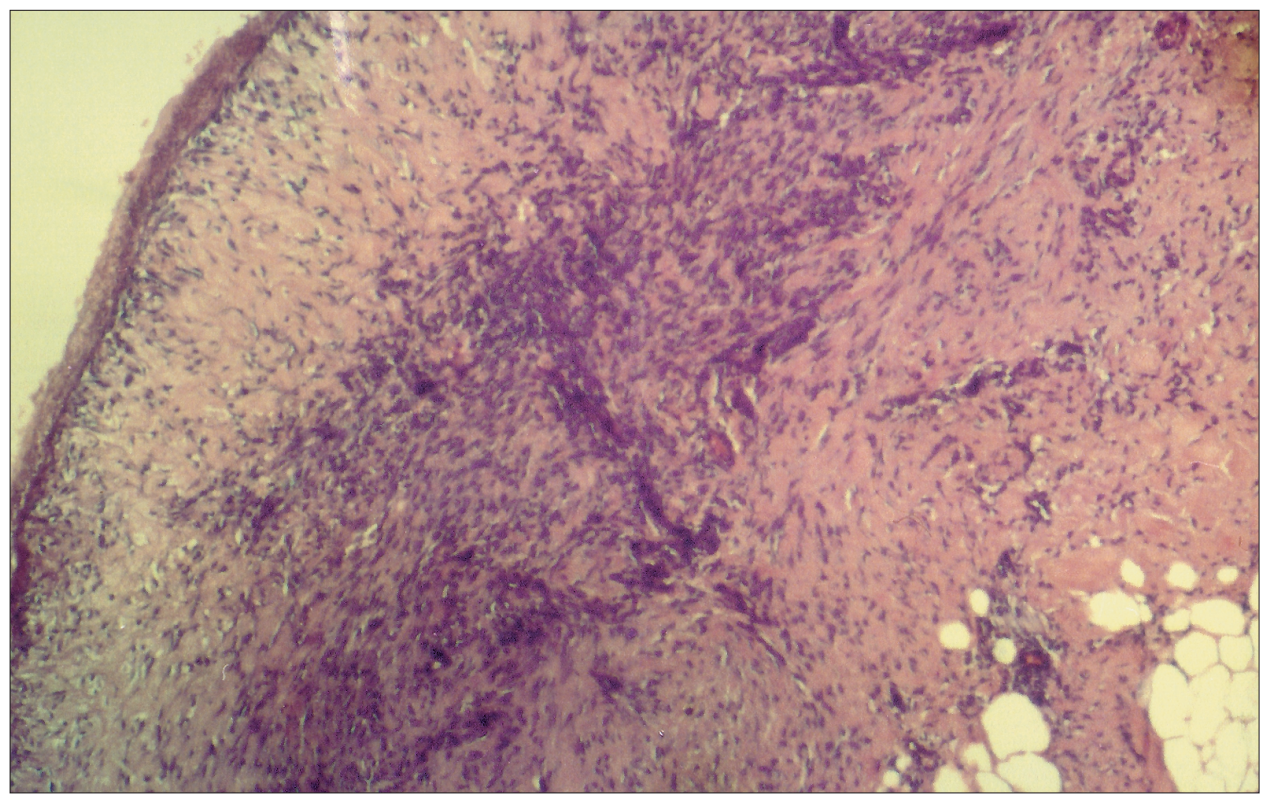

Fig. 9. Typical histologic view of wounds $1-4$ before overgrafting (day 10 post injury). The surface of vascularised dermal substitute covered by condensated layer of fibroblasts creating the outer barrier in wounds 1-4 without any difference. Below this layer reticular pattern of connective tissue is visible. Deeper continual layer of inflammatory cells can be seen. (HE) .

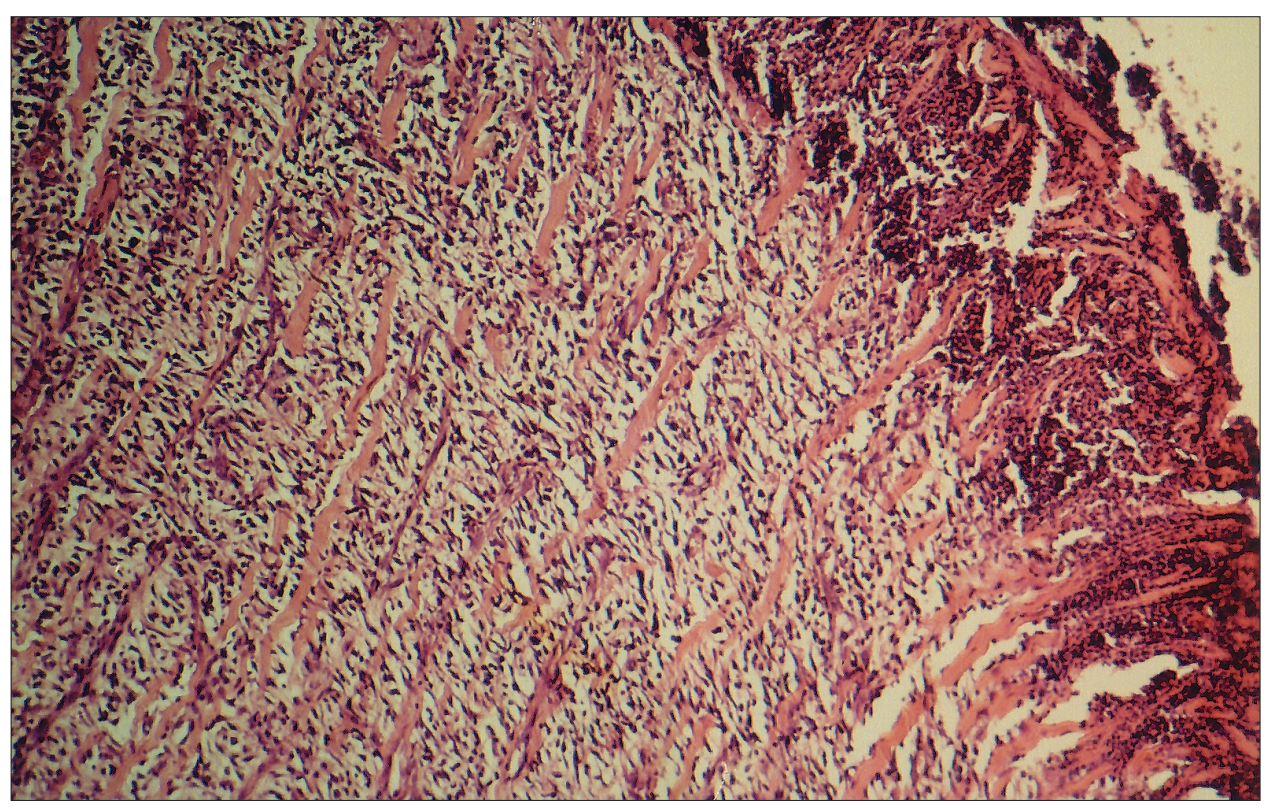

Fig. 10. The typical histologic view of wounds 1-4 seven days after overgrafting. On the surface there is a layer of partially necrotic material, below this layer tangentially oriented collagen fibres. From the deeper layers the radially oriented collagen fibres are growing. In the dermoepidermal graft, necrotic areas can be seen and, in addition, undoubtedly live fibroblasts and keratinocytes (HE). 
Plate VIII

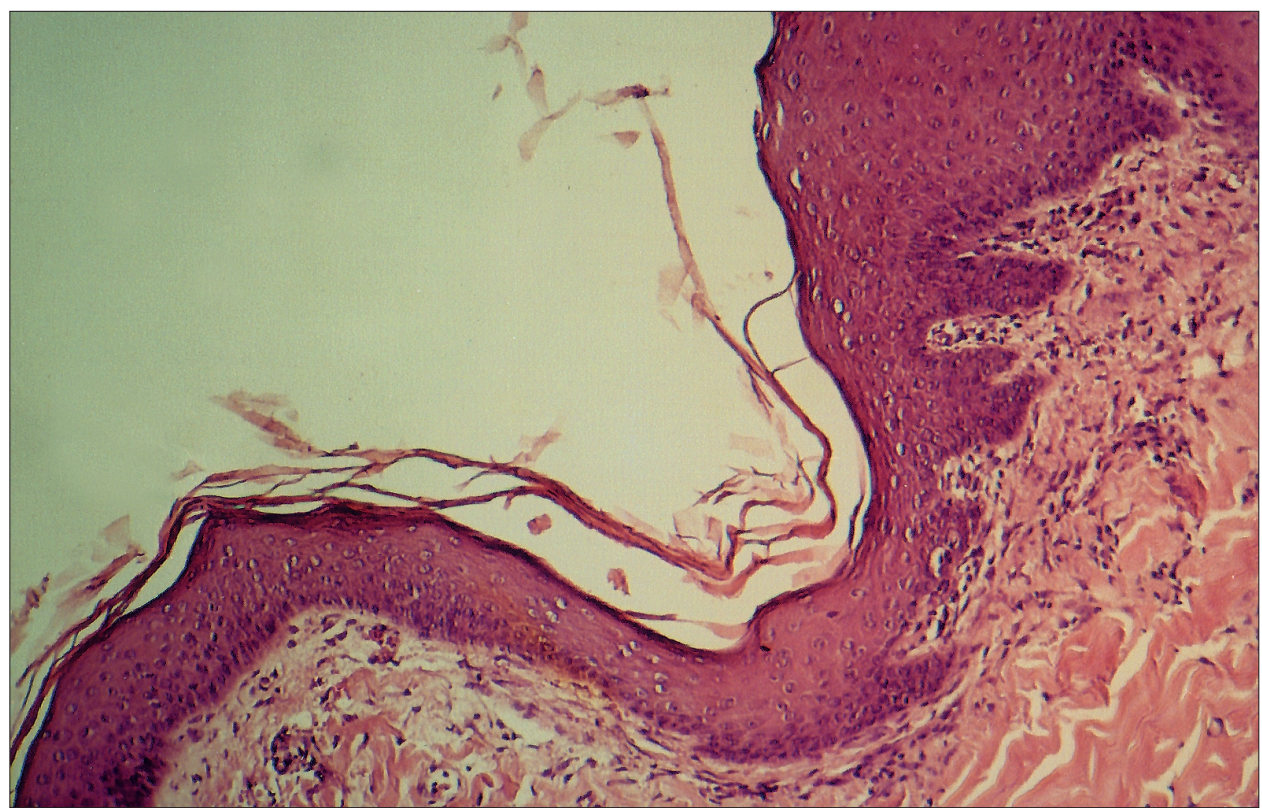

Fig. 11. The histologic picture of wounds 1-4 on day 31 after injury shows the structure of the graft closely similar to normal skin. The main differences: a) flat rete ridges compared to normal skin, b) thinner epidermis compared to normal skin, c) fine collagen bundles mostly tangentially oriented, d) low cellularity comparable to normal skin. (Left half of the picture - composite graft, right half of the picture - intact skin. HE).

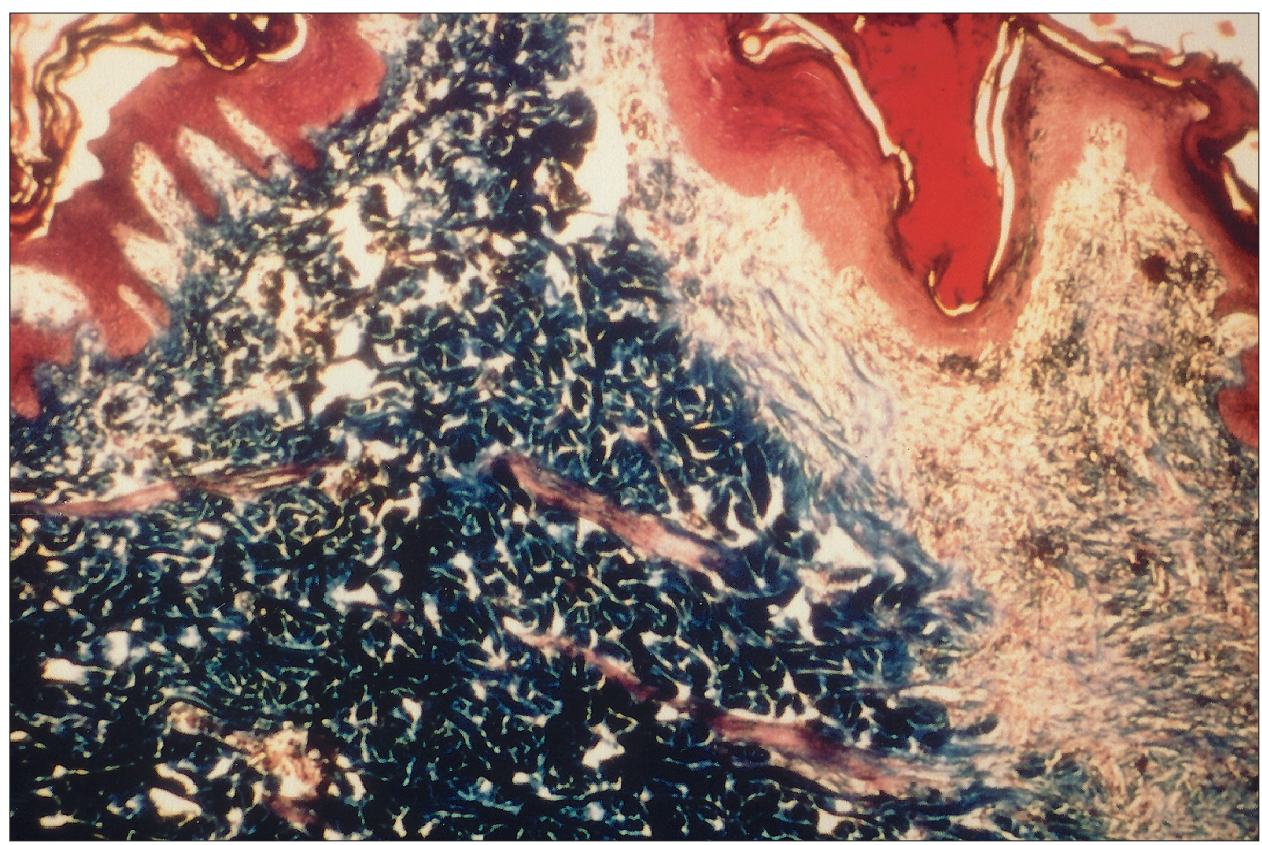

Fig. 12. The same situation, another staining. Note the finer collagen bundles in the graft (right) than in normal skin (left). AZAN staining 